\title{
ADENOID VEGETATIONS - RESERVOIR OF BACTERIA FOR CHRONIC OTITIS MEDIA WITH EFFUSION AND CHRONIC RHINOSINUSITIS
}

\author{
Marina Davcheva-Chakar', Ana Kaftandzhieva ${ }^{2}$, Beti Zafirovska ${ }^{3}$ \\ ${ }^{1}$ University ENT Clinic, Medical Faculty, Skopje, R. Macedonia \\ ${ }^{2}$ Institute of Microbiology and Parasitology, Medical Faculty, Skopje, R. Macedonia \\ ${ }^{3}$ Institute of Epidemiology and Biostatistics with Medical Informatics, Medical Faculty, \\ Skopje, R. Macedonia
}

Corresponding Author: Marina Davcheva-Chakar, University ENT Clinic, Medical Faculty, 1000 Skopje, R. Macedonia; Tel: +38970330553; E-mail: marinacakar@yahoo.com

\begin{abstract}
Introduction: Otitis media and rhinosinusitis are commonly encountered illnesses in pediatric population. Literature reports have documented the association between the occurrence of these two conditions and even their almost identical microbiological findings. Until recently, the key factor in the association of these two conditions was considered to be the hypertrophic adenoid tissue, but within the past few years there have been evidences in the literature about the presence of bacterial biofilms on the adenoids suggesting biofilms to be also responsible for both conditions, chronic otitis media with effusion and chronic rhinosinusitis.

Aim: The aim of this study was to make a microbiological analysis of the adenoid tissue specimens taken from patients with chronic otitis media with effusion and chronic or recurrent rhinosinusitis and to determine their potential for biofilms formation.

Methods: After the surgical intervention, adenoidectomy, microbiological evaluation and analysis of the adenoid tissue specimens taken from 20 patients were made. Having in mind the disease history, chronic otitis media with effusion was diagnosed in all 20 patients and chronic rhinosinusitis in 9 patients.

Results: The results obtained from the microbiological analyses showed many potentially pathogenic bacteria in the adenoids that were almost identical with the most common organisms incorporated in the etiopathogenesis of both conditions, in chronic otitis media with effusion and in chronic rhinosinusitis. In 7 (35\%) patients Haemophylus influenzae was isolated, in $6(30 \%)$ Streptococcus pneumoniae, in 4 (20\%) Moraxella catarrhalis, in $2(10 \%)$ patients Staphylococcus aureus and in 1 (5\%) patient Streptococcus pyogenes - group A was isolated. One bacterium was isolated from all adenoid vegetations, except in one case when two bacteria (Haemophylus influenzae and Staphylococcus aureus) were concurrently isolated.

Conclusion: Our results have shown that the key role in adenoid vegetations in chronic otitis media with effusion and chronic rhinosinusitis is not only the mechanism of rhinopharyngeal obstruction, but also the presence of bacterial strains with a large potential for formation of biofilms adhered to their surface, especially in cases with symptoms of chronic otitis media with effusion and chronic rhinosinusitis that were resistant to antibiotic therapy.
\end{abstract}

Key words: adenoid vegetations, bacterial reservoir, chronic otitis media with effusion, chronic rhinosinusitis

\section{Introduction}

Otitis media with effusion and rhinosinusitis are commonly encountered illnesses in pe- diatric population. According to the literature $43 \%-47 \%$ of the children with diagnosed otitis media with effusion have concurrent sinusitis 
$[1,2]$, and $23 \%$ of the patients with chronic sinusitis have otitis media with effusion [3]. A large percentage of the children $(78 \%)$ with otitis media with effusion, who did not respond to the effect of the anti-inflammatory therapy, had concurrent rhinosinusitis. In children with a combination of otitis media and sinusitis microbiological findings from the middle ear, the effusions were identical with the sinus aspirates [4].

The failure of the antibiotic treatment in the eradication of suspicious organisms has motivated microbiologists to hypothesize the presence of a bacterial community organized and attached to the organic and inorganic surfaces, the so-called biofilm [5, 6]. A biofilm is a colony of one or several bacterial strains embedded in a polymer matrix of their own, which is composed of nucleic acids, polysaccharides and proteins. In comparison with the planktonic form, the biofilm matrix protects the microorganisms, provides better survival and protects them from the effect of the macrophages, antibiotics, fluctuations in temperature and $\mathrm{pH}$. The successful survival of bacteria by biofilm formation is a subject of investigation of many authors [7-9], in order to define the role of the biofilm in the etiopathogenetic mechanism of the antibiotic resistance as well as in the chronic course of the upper respiratory tract inflammatory processes. The latest publications from the Center for Disease Control and Prevention have reported that $65 \%$ of the human bacterial infections involve biofilms [10].

The aim of this study was to determine the most common microorganisms in the tissue specimens of adenoid vegetations in patients with chronic otitis media with effusion (COME) and chronic rhinosinusitis (CRS) resistant to anti-inflammatory treatment, as a result of which a surgical intervention i.e. adenoiddeadenoidctomy was performed.

\section{Material and methods}

A total of 20 adenoid tissue specimens were examined. They were taken from children (12 boys and 8 girls of an average age of six years) hospitalized at the University Ear, Nose and Throat Clinic. The patients' history revealed that all children had recurrent or chronic inflammation of the middle ear, and 9 of these children had concurrent chronic rhinosinusitis. Adenoidectomy was performed in 15 children and adenotonsillectomy in 5 children.

Each specimen was rinsed and put in a sterile bottle with physiologic solution and sent for microbiological examination and analysis at the Institute of Microbiology and Parasitology, Medical Faculty in Skopje. All specimens were analyzed with standard microbiological techniques. The specimens were inoculated on four solid and one liquid media. Each specimen was inoculated on the following media for bacteria isolation: blood agar (for isolation of aerobic bacteria), Schaedler agar (for isolation of anaerobic bacteria), chocolate agar (for isolation of Haemophilus), liquid medium - glucose broth (for faster bacterial growth) and Sabouraud agar for fungi isolation. All media were from the manufacturer Oxoid, UK. From each specimen a direct microscopic specimen was made and it was stained by Gram staining method showing the eventually present leukocytes and bacteria. Susceptibility to different groups of antibiotics was examined in all isolated bacteria by application of the standard disc diffusion method. The following antibiotic discs were tested: from the penicillin group - penicillin, ampicillin, cloxacillin, amoxicillin-clavulanic acid, vancomycin; cephalosporins - cefadroxil, cefpodoxime, ceftriaxone, cefotaxime; aminoglycosides - amikacin; lincosamines - clindamycin; macrolides - erythromycin; quinolone ciprofloxacin and cotrimoxazole. All discs were from the manufacturer Oxoid, UK in concentrations corresponding to the CLSI (Clinical and Laboratory Standard Institute) standards. The results from the disc diffusion method were also interpreted according to the CLSI standards.

The statistical analysis was made with the statistical program SPSS for Windows, 17.0. The data are presented as absolute or relative numbers. For comparison of the isolates found in children with COME and with COME and CRS Fischer's exact, two-tailed test was used. The values of $p<0.05$ were considered to be statistically significant.

\section{Results}

The microbiological results were positive in all 20 adenoid tissue specimens. In the lar- 
gest percentage $(35 \%)$ of specimens Haemophilus influenzae was isolated, followed by Streptococcus pneumoniae (30\%), Moraxella catarrhalis (20\%), Staphylococcus aureus (10\%) and Streptococcus pyogenes - group A (5\%).

The statistical analysis of the presence of different types of bacteria showed no significant difference of Haemophilus influenzae, Streptococcus pneumoniae, Streptococcus pyogenes, Moraxella catarrhalis and Staphylococ- cus aureus between the group of children with COME and children with both COME and CRS.

Haemophilus influenzae and Streptococcus pneumoniae were more frequently isolated from adenoids of children with COME and CRS while Streptococcus pyogenes, Moraxella catarrhalis and Staphylococcus aureus were more frequently isolated from adenoids of children with COME (Table 1).

Table 1

Isolates from children with COME and from children with COME and CRS

\begin{tabular}{|c|c|c|c|}
\hline Organisms & $\begin{array}{c}\text { Number of } \\
\text { isolates-COME } \\
(\mathrm{n}=20)\end{array}$ & $\begin{array}{c}\text { Number }(\%) \text { of } \\
\text { isolates-COME+CRS } \\
(\mathrm{n}=9)\end{array}$ & $\mathrm{p}$-value \\
\hline H. influenzae & $8(40 \%)$ & $4(44.5 \%)$ & $\mathrm{p}=1.0$ \\
\hline St. pneumoniae & $6(30 \%)$ & $4(44.5 \%)$ & $\mathrm{p}=0.67$ \\
\hline St. pyogenes & $1(5 \%)$ & 0 & $\mathrm{p}=1.0$ \\
\hline M. catarrhalis & $4(20 \%)$ & $1(11 \%)$ & $\mathrm{p}=1.0$ \\
\hline St. Aureus & $2(10 \%)$ & 0 & $\mathrm{p}=1.0$ \\
\hline
\end{tabular}

$\mathrm{P}$ (Fisher exact, two tailed)

The results obtained for the susceptibility of microorganisms to certain antibiotics showed that Haemophilus influenzae, Streptococcus pyogenes and Staphylococcus aureus strains were susceptible to all tested antibiotics, except to cotrimoxazole. Mild susceptibility and resistance to certain antibiotics was found for Streptococcus pneumoniae and Moraxella catarrhalis isolates (Table 2).

Table 2

Susceptibility of isolates to antibiotics

\begin{tabular}{|c|c|c|c|c|c|c|c|c|c|c|c|c|c|c|}
\hline Pathogenic & \multicolumn{14}{|c|}{ Antibiotics - $(\mathrm{S}, \mathrm{I}, \mathrm{R})$} \\
\hline $\begin{array}{l}\text { Bacteria/numb } \\
\text { er of patients }\end{array}$ & $\begin{array}{l}. \Xi \\
: 0 \\
.00 \\
0\end{array}$ & 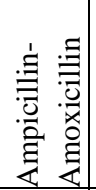 & 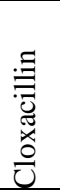 & 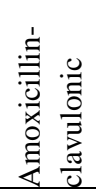 & 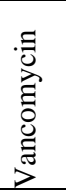 & 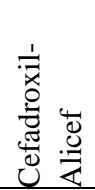 & 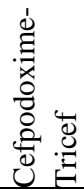 & 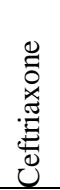 & 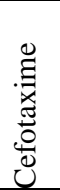 & 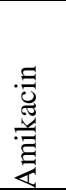 & 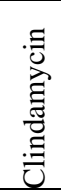 & 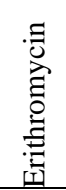 & 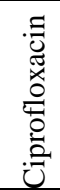 & $\begin{array}{l}\frac{0}{0} \\
0 \\
\widetilde{x} \\
0 \\
0 \\
0 \\
0 \\
0\end{array}$ \\
\hline M. catarrhalis & 4-R & 4-R & $4-\mathrm{S}$ & $4-\mathrm{R}$ & 4-R & $4-\mathrm{I}$ & $4-S$ & 4-S & 4-I & $4-\mathrm{I}$ & 4-I & $4-S$ & $4-S$ & 4-R \\
\hline St. pyogenes & $1-S$ & $1-S$ & $1-\mathrm{S}$ & $1-\mathrm{S}$ & $1-\mathrm{S}$ & $1-\mathrm{S}$ & $1-\mathrm{S}$ & $1-S$ & $1-\mathrm{S}$ & $1-S$ & $1-\mathrm{S}$ & $1-S$ & $1-\mathrm{S}$ & $1-\mathrm{R}$ \\
\hline St. Pneumoniae & 6-I & $6-\mathrm{I}$ & $6-\mathrm{I}$ & $6-S$ & $6 \mathrm{~S}$ & $6-S$ & $6-S$ & $6-S$ & $6-\mathrm{R}$ & $6-S$ & $6-S$ & $6-\mathrm{R}$ & $6-S$ & $6-\mathrm{R}$ \\
\hline H. influenzale & $7-S$ & $7-S$ & $7-\mathrm{S}$ & $7-S$ & $7-S$ & $7-S$ & 7-S & $7-S$ & $7-S$ & $7-S$ & $7-S$ & $7-S$ & $7-S$ & $7-\mathrm{R}$ \\
\hline St. aureus & $2-S$ & $2-S$ & $2-S$ & $2-S$ & $2-S$ & $2-S$ & $2-S$ & $2-S$ & $2-S$ & $2-S$ & $2-S$ & $2-S$ & $2-S$ & $2-S$ \\
\hline
\end{tabular}

Legend: S-susceptible; I-moderately susceptible; R-resistant

\section{Discussion}

Hypertrophic adenoid vegetations support the development of COME and COME causing mechanical obstruction of choanae and Eustachian tube, which results in secretion sta- sis in nasal fosse and middle ear [11]. In addition to the effect of obstruction, recent investigations have emphasized that adenoids might act as a reservoir of pathogenic bacteria in both conditions, in COME and COM [12]. The re- 
duction in the number of COME episodes following adenoidectomy in children > 3 years, independently of the adenoid's size, suggests that the mechanical obstruction in the upper respiratory tract is not the unique risk factor for recurrent COME [13]. The debate about this bacterial reservoir and its role in the etiology of these two clinical entities is still open. The results presented in one study including a large number of children showed that COME and CRS were found in $11 \%$ of the total number of children who did not have adenoids, and the percentage was significantly increased up to $50 \%$ in children with adenoid vegetations [14].

Recently a group of authors introduced a fluorescent in situ hybridization (FISH), and immunostaining combined with confocal laser scanning microscope to prove that bacterial strains in adenoid and tonsil tissue specimens were identical with the pathogens commonly isolated in patients with chronic infections [15]. Other authors have demonstrated that the percentage of Haemophilus influenzae decreases with the increasing age [16].

In the study of Galli et al. [17] biofilms were identified in $100 \%$ of samples, and Haemophilus influenzae was the most commonly isolated bacteria in adenoid tissue.

One study has shown that Haemophilus influenzae has a large propensity of in vitro biofilm formation. This observation might be associated with the physiologic state that differs from that of the bacteria growing in a planktonic form, which might explain the unresponsiveness to antibiotic treatment [18]. As an opportunistic pathogenic bacterium Haemophilus influenzae coexists with other organisms in the nasopharynx. Its transmission into pathogen happens most probably due to variations in the protection system such as alterations in mucocilliary transport and Eustachian tube dysfunction [19].

In this study there was no statistically significant difference in the incidence of Haemophilus influenzae, Streptococcus pneumoniae, Streptococcus pyogenes and Staphylococcus aureus, M. catarrhalis and St. aureus between children with COME and children with both COME and CRS suggesting interference of these two conditions with adenoids from which these potentially pathogenic bacteria were isolated.

Our results are similar with other presented in a large number of studies indicating that adenoidectomy is effective in the treatment of COME and CRS, having in mind that adenoids act as a reservoir of pathogenic bacteria and play an important role in the pathogenesis of these two conditions [13, 20-22].

The analyses about the susceptibility of microorganisms to certain antibiotics have shown that Haemophilus influenzae, Streptococcus pyogenes, Moraxella catarrhalis and Staphylococcus aureus were susceptible to all tested antibiotics, except to cotrimoxazole to which Haemophilus influenzae and Streptococcus pyogenes were resistant. Mild susceptibility and resistance to certain antibiotics was observed in Streptococcus pneumoniae and Moraxella catarrhalis isolates. This result suggests the need for treatment of these conditions in line with the microbiological finding and antibiogram.

\section{Conclusion}

The treatment of COME and CRS in the pediatric population is still an issue under discussion among the specialists in otorhinolaryngology and microbiology.

In this study the microbiological findings obtained from the adenoid tissue specimens of patients with COME and CRS have indicated that isolated bacteria might form a biofilm, which on the other hand might be a reservoir of pathogens for COME and CRS. This has a substantial diagnostic-therapeutic importance.

Based on the results obtained we assume adenoidectomy, independently on the size of the adenoid vegetation, to be justifiable in children with COME and CRS.

The results of in vitro tests of bacterial susceptibility to certain antibiotics have pointed out the need of a greater collaboration between the otorhinolaryngologists and microbiologists in order to suggest the most adequate antibiotic agent in treatment of chronic rhinosinusitis and otitis media.

To prevent the ability of bacteria to form a biofilm as well as to prevent biofilm formation it is necessary to develop a biofilm-related 
method. All methods for detection of biofilms are not available for routine work, except in highly specialized research centers. There are still no methods for routine detection of biofilms and hence the effective intervention depends on the quality of the clinical diagnosis.

\section{REFERENCES}

1. Hoshaw TC, Nickman NJ. Sinusitis and otitis in children. Arch Otolaryngol. 1974; 100: 194-5.

2. Grote JJ, Kjuipers W. Middle ear effusion and sinusitis. J Laryngol Otol. 1980; 94: 177-83.

3. Finkelstein Y, Talmiy P, Rubel Y, Bar-Ziv J, Zohar Y. Otitis media with effusions as a presenting symptom of chronic sinusitis. J Laryngol Otol. 1989; 103: 827-32.

4. Brook I, Yocum P, Shah K. Aerobic and anaerobic bacteriology of concurrent chronic otitis media with effusion in and chronic sinusitis in children. Arch Otolaryngol Head Neck Surg. 2000; 126: 174-176.

5. Fergie N, Baystone R, Pearson JP, Birchall JP. Is it otitis media with effusion a biofilm infection? Clinical Otolaryngol. 2004; 29: 38-46.

6. Stoodley HL, Costerton JW, Stoodley P. Bacterial biofilms from tha natural environment to infectious diseases. Nat Rev Microbiol. 2004; 2: 1-15.

7. Stewart PS, Costerton JW. Antibiotic resistance of bacteria in biofilms. Lancet. 2001; 358: 135-8.

8. Costerton JW, Stewart PS, Greenberg EP. Bacterial biofilm. A common cause of persistent infections. Science. 1999; 284: 1318-1322.

9. Post JC, Stoodley P, Stoodle LH, Ehrlich GD. The role of biofilms in otolaryngology infections. Otolaryngol Haed Neck Surg. 2004; 12: 185-90.

10. Potera C. Forging a link between biofilms and disease. Science. 1999; 284: 1837-9.

11. Van Cauwuenberge PB, BellussiL, Maw AR, Paradise R, Solow B. The adenoid as a key factor in upper airway infections. Int J Pediatr Otorhinolaryngol. 1995; 32 (suppl): 571-80.

12. Marschisio P, Ghisalberti E, Fusi M, Baggi E, Raggazi M, Dusi E. Paranasal sinuses and middle ear infections: what do they have in common? Pediatr Allergy Immunol. 2007; 18 (Suppl. 8); 31-34.

13. Nistico L, Kreft A, Giesece J, Coticchia M, Burrows A, et al. Adenoid reservoir for pathogenic biofilm bacteria. J Clin Microbiol. 2011; Vol. 49: 1411-20.

14. Marseglia GL, Pagella F, Caimmi S, Castellazzi AM, Poddighe D, Klersy C, Ciprandi G. Increased risk of otitis media with effusion in allergic children presenting with adenoiditis. Otolaryngol Head Neck Surg. 2008; 138: 572-75

15. Hall-Stoodley L, Hu Fz, Gieseke A, Nistico L, Nguyen D, Hayes J, et al. Direct detection of bacterial biofilms of the middle-ear mucosa of children with chronic otitis media. JAMA. 2006; 296: 202-11.
16. Swidsinski A, Gogdas O, Bessler C, Loening-Baucke $\mathrm{V}$, Hale LP, Andree H, et al. Spatial organization of microbiota in quiescent adenoiditis an tonsillitis. $\mathbf{J}$ Clin Pathol. 2006; 12.

17. Galli J, Calo J, Ardito F, Imperiali M, Bassotti E, Fadda G, Paludetti G. Biofilm formation by Haemophilus influenzae isolated from adeno-tonsil tissue samples, and its role in recurrent adenotonsillitis. Acta Otorhinolaryngol Ital. 2007; 27 (3): 134-138.

18. Murphy TF, Kirham C. Biofilm formation by nontypeable Haemophillus Influenzae: strain variability, outer membrane antigen expression and role of piuli. BMC Microbiol. 2001; 2: 7.

19. Webster P, Wu S, Gomez G, Apicella M, Plaut AG, St Geme JW $3^{\text {rd }}$. Distribution of bacterial proteins in biofilms formed by non-typeable Haemophilus influenza. J Histohchem Cytochem. 2006; 54: 829-42.

20. Pagella F, Colombo A, Gatti O, Giourgos G, Matti E. Rhinosinusitis and otitis media: the link with adenoids. Int J Immunopathol Pharmacol. 2010; Vol. 23, no1: 38-40.

21. Saafan ME, Ibrahim WS, Tomoum MO. Role of adenoid biofilm in chronic otitis media with effusion in children. Euro Arch Otorhinolaryngol. 2013; 270(9): 2417-25.

22. Torrente S, Dragon L, Machismo P, Gaffer M, Clemente IA, Pignataro L. Topographic distribution of biofilm -producing bacteria in adenoid subsites of children with chronic or recurrent middle ear infections. Ann Otol Rhinol Larynogl. 2013; 122(2): 109-13.

Резиме

\section{АДЕНОИДИ ВЕГЕТАЦИИ - РЕЗЕРВОАР НА БАКТЕРИИ ЗА ХРОНИЧЕН ОТИТИС МЕДИЈА СО ЕФУЗИЈА И ХРОНИЧЕН РИНОСИНУСИТИС}

\section{Марина Давчева-Чакар ${ }^{1}$, Ана Кафтаншиева ${ }^{2}$, Бети Зафировска ${ }^{3}$}

${ }^{1}$ Универзитетска клиника за уво, нос и грло, Медицински факултет, Скопје, Р. Македонија ${ }^{2}$ Институт за микробиологија и паразитологија, Медицински факултет, Скопје, Р. Македонија ${ }^{3}$ Институт за епидемиологија и биостатистика со медицинска информатика, Медицински факултет, Скопје, Р. Македонија

Boвeg: Риносинуситис и отитис медија се заболувања кои многу често се сретнуваат во педијатриската популација. Во литературата јасно е потврдена асоцијацијата помеѓу овие две состојби и дури е потврдено совпаѓање на нив- 
ните микробиолошки наоди. До неодамна се сметаше дека клучен фактор што ги поврзува овие две состојби е хипертрофичното аденоидно ткиво, но од пред неколку години литературата опишува присуство на бактериски биофилм на аденоидите, што сугерира дека биофилмот, исто така, е одговорен за двете состојби за хроничен отитис медија со ефузија и за хроничен риносинуситис.

Цел: Оваа студија имаше цел да се утврди и за се направи микробиолошка анализа на аденоидното ткиво кај пациенти со отитис медија и хроничен/или рекурентен риносинуситис и да се одреди нивниот потенцијал за формирање на биофилм.

Meӣоgи: По спроведена хируршка интервенција, аденоидектомија, беше направена микробиолошка евалуација и анализа на аденоидното ткиво кај 20 пациенти. Според податоците од историјата на болеста, кај сите 20 пациенти беше дијагностициран хроничен отитис медија со ефузија, а кај деветмина од вкупниот број пациенти беше верифициран хроничен риносинуситис.

Резулйайи: Резултатите од микробиолошката анализа покажаа дека аденоидите содржат многу потенцијално патогени бактерии, кои се поклопуваат со најчестите организми инкор- порирани во етиопатогенезата на двете состојби риносинуситис и отитис медија со ефузија. Кај седумина (35\%) пациенти беше изолиран Нaеmophylus influenzae, кај шестмина (30\%) беше изолиран Streptococcus pneumoniae, а потоа следуваа Moraxella catarrhalis изолирана од четворица (20\%) пациенти, Staphylococcus aureus кај двајца пациенти (10\%) беше изолиран и Streptococcus pyogenes кај еден пациент $(5 \%)$. Од сите аденоидни вегетации беше изолирана по една бактерија, освен во еден случај кога беа истовремено изолирани две бактерии: Haemophylus influenzae и Staphylococcus aureus.

Заклучок: Резултатите од овој труд покажуваат дека клучната улога на аденоидните вегетации кај хроничните риносинусити и отитис медија со ефузија не е само механизмот на ринофарингеална опструкција, туку и присуството на бактериски соеви со голем потенцијал за формирање биофилм на нивната површина, особено кај случаи со симптоми на хроничен риносинуситис и хроничен отитис медија со ефузија, кои беа отпорни на антибиотска терапија.

Клучни зборови: аденоидни вегетации, бактериски резервоар, хроничен отитис медија со ефузија, хроничен риносинуситис 